\title{
Linking Institutional Environment to the IFRS and Accounting Quality: A Proposed Framework
}

\author{
Fuad*, Zulaikha, Agung Juliarto \\ Department of Accounting, Faculty of Economics and Business, Universitas Diponegoro, Indonesia
}

Received February 13, 2021; Revised April 1, 2021; Accepted May 16, 2021

\section{Cite This Paper in the following Citation Styles}

(a): [1] Fuad, Zulaikha, Agung Juliarto, "Linking Institutional Environment to the IFRS and Accounting Quality: A Proposed Framework," Universal Journal of Accounting and Finance, Vol. 9, No. 3, pp. 347 - 351, 2021. DOI: 10.13189/ujaf.2021.090308.

(b): Fuad, Zulaikha, Agung Juliarto (2021). Linking Institutional Environment to the IFRS and Accounting Quality: A Proposed Framework. Universal Journal of Accounting and Finance, 9(3), 347 - 351. DOI: 10.13189/ujaf.2021.090308.

Copyright $\mathrm{C} 2021$ by authors, all rights reserved. Authors agree that this article remains permanently open access under the terms of the Creative Commons Attribution License 4.0 International License

\begin{abstract}
Debates on whether the new globally adopted accounting standard outperforms national generally accepted accounting principles have not yet reached the final conclusion. Prior researches were mixed and often yield to contradictory findings. Our study believes that there are numerous institutional backgrounds that contribute to these inconclusive findings. The main objective of this study is to propose a testable framework on the impact of implementation of International Financial Reporting Standards on accounting qualities. The proposed framework based on the assumption that accounting should be linked to its social, political influences and culture. In this regard, we proposed whether the positive effects of IFRS implementation to the increase of accounting qualities may also be enhanced (impaired) by the firms' national culture and corruption at the country level. This study should provide further research some preliminary arguments on how the accounting information quality is not affected by the high-quality accounting standards, per se. Rather, our study conveys worth-looking message that IFRS-accounting quality may also be influenced by those institutional environments. Hopefully, this may provide a way out of the intractable debate of prior research.
\end{abstract}

Keywords Accounting Quality, IFRS, Corruption, National Culture

\section{Introduction}

Most countries in the world have accepted International Financial Reporting Standards (IFRS) as the firms' accounting standards. As of 2018, it has been reported that more than 130 countries have converged or adopted to IFRS from national Generally Accepted Accounting Principles (herewith, GAAP). At least there are several differences between IFRS and GAAP. One main notable difference is that IFRS is a principles-based approach that allows for different interpretation of a particular transaction. GAAP on the other hand provides more details, offering stricter guidelines in preparing the financial reporting [29].

Nevertheless, debate about this issue has not yet reached the final conclusion on whether one particular standard outperforms another [13]. For example, IFRS proponents maintained that IFRS could increase financial statements comparability and minimize reconciliation costs [6]. On the other hand, few others have also suggested that IFRS may be problematic in several ways. First, IFRS encourage small and medium enterprises to cover unnecessary expenses in order to implement it [2]. Second, IFRS has not yet been able to prove to produce better accounting qualities [1]. Third, earnings management may also increase because IFRS provides flexibility in its implementation $[9,11]$

Not surprising therefore, researches were not in agreement whether the IFRS adoption would lead to better financial reporting quality. For example, while [5], [30] among others found that accounting qualities, other researchers found no such improvement (e.g. [18,19,20,26, among others]). Our study speculates that it is very likely that differences of accounting quality caused by IFRS is not linear, but there are some other institutional factors that 
affecting it. References [14], [10] [4] maintained that differences of accounting quality can sometimes be observed due to different environmental attributes.

One of the important attributes reflecting environmental factors that was rarely researched in relation to IFRS-accounting quality is corruption and national culture. Reference [25] stated that research is limited when it comes to linking corruption and accounting, but not alone accounting quality. Although [25] argued that corruption in business and management settings have been widely researched. In a similar vein, [31] also argued that accounting researchers were not interested in corruption issues, although [7] have suggested that the output of financial reporting is heavily influenced countries' legal settings (i.e. corruption level), in their study on the relations of auditing, accounting transparency and enforcement bodies.

Some studies have provided convincing finding that corruption culture has a destructive effect towards accounting quality. Using the data from China's local public firms, [12] found that firms accounting quality that are affiliated with the corrupt officials tend to have higher accounting quality after the arrest of the officials. This finding provides a solid argument that strong regulatory environment has a pivotal role in determining the quality of accounting information. Nevertheless, we do not propose the corruption culture affecting accounting per se. Rather, we argue that how the positive consequences of IFRS brings to the enhancement of accounting quality increases more with stronger regulatory environment.

Reference [41] maintained that any economic consequences of IFRS adoption would be diminished in the state of higher corruption culture. The stronger effect of IFRS on the accounting quality is also observed by [5]. In this regards, firms adopting IFRS may encourage firms to have better transparency and accountability that could yield to higher accounting quality.

Besides corruption, some researchers also insisted that national culture provides a significant effect on how management use their discretion in order to manipulate earnings [16,23]. With regard to IFRS, [21] found that national culture and earnings management are inter-related even after IFRS implementation. Our study proposes whether the positive consequences of IFRS to accounting quality is influenced by national culture in which the firms operate. This positive effect of IFRS and accounting quality stem from the fact that IFRS may, although little, provides some advantage in reducing earnings management.

Indeed, the quality of accounting information is also determined by many diverse national culture. Similarly, although as previously mentioned a lot of empirical evidences have been conducted in testing the implication of IFRS implementation, [36] stated that limited studies focused on the factors that may accelerate or decelerate the IFRS implementation. [33] also agreed that firms' compliance levels of IFRS differ across countries and times as well. Based on this, we provide a testable conceptual framework that should provide a path on figuring out the reasons for the conflicting findings of international accounting standards implementation and accounting quality.

This study suggests that earnings smoothing, accounting conservatism and earnings management may be the proxies for the quality because they are the most accurate ways in reflecting managerial discretion to make financial and accounting choices, which results in accounting performance distortion [28]. They may also be used as a proxy in measuring firms' potentials to mislead wider stakeholders, including shareholders, banks, customers and financial intermediaries. On the other hand, accounting conservatism may also reflect the accounting quality on which how the firms respond to recognize asymmetrically the bad news in contrary to the good news.

\section{Propositions}

\section{Accounting, Corruption and National Culture}

Accounting has long been known to be a paramount factor in new public management. This is because accounting may act as a barrier and promote the strong accountability framework. Not surprisingly therefore, many global financial institutions such as International Monetary Funds or World Bank encourage the countries to adopt accrual accounting systems. A shift from accounting cash basis that hopefully could provide a more transparent and reliable accounting information.

Reference of [33] argued that corruption does necessarily affect the public sector per se. Rather it is becoming a common issue in the private and corporate world, even among more developed countries.

National culture, a term pioneered by Hofstede in his seminal books in 1991 and 2001, is defined as a measure in which how the social environment structurally affects how people around the world would think and act. He argued that the patterns of structural environmental (e.g., school, living community, etc.) affect the individuals actions can be observed at the country level, and therefore, the extent of national culture differ among nations. More specifically, he defined national culture as "the collective programming of the mind which distinguishes the members of one group or category of people from another" (p. 260).

Using a sample from more than 110,000 from 50 countries, he identified several dimensions of the national culture:

\section{a. Power distance}

It can be defined as the extent to which individuals can tolerate and accept that the power may unequally be distributed to members of the communities, organizations 
or societies.

\section{b. Individualism}

Individualism (vs. collectivism) measures the extent to which individuals may put more emphasis on either value group contribution or personal contribution. This dimension also measures the individuals' preferences on being a part of group or the individual right for freedom.

\section{c. Uncertainty avoidance}

This dimension measures on how comfortable people of a particular nation for any contingencies, ambiguity or uncertainty. Higher uncertainty avoidance culture is more likely to have more stress, anxiety and higher expression on emotions.

\section{d. Masculinity}

Masculinity (or feminism, vice versa) can be simply defined as the extent to which individuals of a particular country value more the "masculine" factors such as strength, performance and success. Lower masculinity score in a nation can be shown by more emphasis on nurturing values such as life quality or personal relationship.

\section{The Declining Positive Consequences of IFRS in High Corruption Culture}

In their limited study settings, [38,40] accounting is influenced by the politics and corruption. Another research conducted by [35] found that corruption in developing countries is influenced by lack of government regulations, which in this case is ambiguous accounting standards. Indeed, researches conclusively insisted that corruption is destructive and has negative consequences on overall firm performance $[8,39]$.

This study assumes that corruption that has been "internalized" in a particular country can easily influence organizational context. Reference [3] argued that corruption can be easily perceived as normal when moral agency declined overtime. In a heavily corrupted country, managers may rationalize this so that earnings smoothing and earnings management are acceptable to increase their wealth.

Although the impact of corruption to accounting is rarely researched, several researches have tried to test the impact of earnings management and earnings opacity on corrupt organizational climate [37,27,34]. Particularly, [34] in their 34 countries study found that low accounting quality increase an unhealthy organizational climate. He also argued that this brought about lack of transparency and accountability. Reference [37] also found that earnings opacity led to corruption in a particular country. Similarly, [17] that conducted a similar study in China, found the positive relation between earnings opacity and corruption. Reference [31] also found that earnings manipulation are higher among firms in highly perceived corruption index. References [15,32] were also in line with the above maintaining that corruption and transparency are interrelated and the corruption is also affected by lack of information asymmetry.

Proposition 1: The positive consequences of IFRS may be dampened for the firms in highly corrupted index.

\section{The Effect of National Culture on the IFRS-Accounting Quality Relationship}

On the other hand, this study also tests the impact of national culture on the positive relationship between IFRS and accounting qualities. More than four decades ago, [24] has observed the need to link accounting with its social, political influences and culture. Hofstede also defined culture as "as collective programming of the mind; it manifests itself not only in values, but in more superficial ways: in symbols, heroes, and rituals".

Many researchers have long contended that cultural domains have very strong effects on accounting practices. For example, the patterns of earnings management, carbon disclosure, tax evasion practices, as well as the extent of corporate governance also differ across national cultures. In a study of 14 member of European Union countries, [22] found that conditional conservatism is higher among the firms with lower individualism.

Nevertheless, this study extends the proposition by testing whether the positive effect between IFRS and accounting qualities (i.e. earnings management and earnings smoothing) is influenced by national culture dimensions. In this case, we test four original cultural dimensions of Hofstede, including power distance, uncertainty avoidance, individualism vs. collectivism, feminism vs. masculinity.

Proposition 2: The positive effect of IFRS to accounting qualities is affected by national culture dimension of firms' particular country.

\section{Conclusions}

This research is motivated by the fact that no conclusive evidences were found on the relationship between IFRS implementation to the accounting qualities. Thus, we propose new lemmas on which the IFRS-accounting qualities are not straight-forwardly linear. More specifically, our study provides proposition on the non-linear effect of IFRS to accounting qualities that is determined by corruption and national culture. This should provide a flourishing new area in providing a way out of intractable debate in whether new, harmonized accounting standards may increase the accounting qualities.

Further research may operationalize those propositions into sound empirical research that can be varied in its flexibilities. For instance, the researchers can use 
multi-dimensional measures of accounting qualities such as earnings management, earnings smoothing, value relevance of accounting information, earnings persistence and so on. Similarly, as the concept of IFRS is broad, further study can look at the impact of various stages of IFRS implementation, from the early convergence process into its full implementation; the voluntary vs. mandatory adoption of IFRS, or just simply the process of IFRS convergence [42]. It is also interesting to figure out the qualitative aspects of IFRS implementation $[44,43,45]$.

\section{REFERENCES}

[1] A. Ahmed, M. Neel, D. Wang. Does mandatory adoption of IFRS improve accounting quality? Preliminary evidence, Contemporary Accounting Research, Vol. 30, pp. 1344 1372,2013

[2] P. Alves, J. Moreira. The adoption of the international financial reporting standards in Portugal: Can expected costs be reduced?, Revista Universo Contabil, Vol 5, pp. 156, 2009

[3] B.E. Ashforth, V. Anand. The normalization of corruption in organizations, Research in Organizational Behavior, Vol. 25, pp. $1-52,2003$

[4] R. Ball. International financial reporting standards (IFRS): pros and cons for investors, Acounting Business Research. Vol. 36 (Suppl. 1), pp. 5-27, 2006

[5] M. Barth, W. Landsman, M. Lang. International accounting standards and accounting quality, Journal of Accounting Research, Vol. 46, pp. 467 -498, 2008.

[6] F. Brochet, J. Jagolinzer, E. Riedl. Mandatory IFRS adoption and financial statement comparability. Contemporary Accounting Research, $1373-1400,2013$

[7] P. Brown, J. Preiato, A. Tarca. Measuring country differences in enforcement of accounting standards: An audit and enforcement proxy, Journal of Business, Finance and Accounting, Vol. 41, pp. 1-52, 2014

[8] C.E., Bryant, R.G. Javalgi, R. G.. Global economic integration in developing countries: The role of corruption and human capital investment, Journal of Business Ethics, Vol. 136, $437-450,2016$

[9] S. Callao, S., J. Jarne. Have IFRS affected earnings management in the European Union?, Accounting in Europe, Vol. 7, pp. $159-189,2010$

[10] J.L. Callen, M. Morel, G. Richardson. Do culture and religion mitigate earnings management? Evidence from a cross-country analysis. International Journal of Disclosure and Governance, Vol. 8, pp. $103-121,2011$

[11] V. Capkun, D. Collins, T. Jeanjean. The effect of IAS/IFRS adoption on earnings management (smoothing): A closer look at competing explanations. Journal of Accounting and Public Policy, Vol 35, pp. 352 -394, 2016

[12] Y. Chen, L. Che, D. Zheng, H. You, Corruption culture and accounting quality. Journal of Accounting and Public Policy,
Vol. 39, pp. 1-22, 2020

[13] S. Collings, The great IFRS debate. Accounting web. Retrieved fromhttp://www.accountingweb.co.uk/topic/finan cial-reporting/great-ifrs-debate/441847, 2015

[14] K. Desender, C. Castro, S. Leon. Earnings management and cultural values, American Journal of Economy and Sociology, Vol. 70, pp. 639-670, 2011

[15] C. DiRienzo, J. Das, K. Cord, J. Burbridge, J. Corruption and the role of information. Journal of International Business Studies, Vol. 38, pp. $320-332,2007$

[16] T. Doupnik. Influence of culture on earnings management: A note. Abacus, Vol. 44, pp. $317-340,2008$

[17] J.P.H. Fan, F. Guan, Z. Li, Y. Yang. Relationship networks and earnings informativeness: Evidence from corruption cases, Journal of Business Finance \& Accounting, Vol. 41, pp. $831-866,2014$

[18] Fuad and W.T. Wijanarto, How mandatory IFRS adoption changes firms' opportunistic behavior: empirical evidences from the earnings management perspective. Academy of Accounting and Financial Studies Journal, Vol. 21pp. 1-10, 2017

[19]Fuad, A. Juliarto, Pujiharto. Does IFRS convergence really increase accounting qualities?: emerging market evidence. Journal of Economics, Finance and Administrative Studies, Vol. 24, pp. 205-220, 2019

[20] G. Gebhardt, Z. Novotny-Farkas, Z., Mandatory IFRS adoption and accounting quality of European banks. Journal of Business, Finance and Accounting. Vol. 38, pp. 289 -333, 2011

[21] S.J. Gray, T. Kang, Z. Lin, Q. Tang. Earnings management in Europe post IFRS: Do cultural influences persist? Management International Review, Vol. 55, pp. 827 -856, 2015

[22] W. Guermazi, and K. Halioui. Do differences in national cultures affect cross-country conditional conservatism behavior under IFRS? Research in International Business and Finance, Vol. 52, pp. 101-171, 2020

[23] S. Han, T. Kang, S. Salter, Y.K. Yoo. A cross-country study on the effects of national culture on earnings management. Journal of International Business Studies, 41(1), 123 -141, 2010

[24] A.G. Hopwood, Editorial: The path ahead. Accounting, Organizations and Society, Vol. 1, pp. 1-4, 1976

[25] M.N. Houqe, T. van Zijl, K. Dunstan, K., W. Karim,. The effect of IFRS adoption and investor protection on earnings quality around the world. International Journal of Accounting. Vol. 47, pp. 333 -358, 2012

[26] T. Jeanjean, H. Stolowy, H. Do accounting standards matter? An exploratory analysis of earnings management before and after IFRS adoption. Journal of Accounting and Public Policy, Vol. 27, pp. $480-494,2008$

[27] M.B. Kimbro. A cross-country empirical investigation of corruption and its relationship to economic, cultural, and monitoring institutions: An examination of F. Mazzi et al. Journal of International Accounting, Auditing and Taxation 31, pp. 52-73, 2002 
[28] A. Klein. Audit committee, board of director characteristics, and earnings management. Journal of Accounting and Economics, Vol 33, pp. $375-400,2002$

[29] S. Kothari, K. Ramanna, D. Skinner, Implications for GAAP from an analysis of positive research in accounting. Journal of Accounting and Economics, pp. 246 -286, 2010

[30] C. Leuz, D. Nanda, Y. Wysocki, Y. Earnings management and investor protection: An international comparison. Journal of Financial Economics, Vol. 69, 2003

[31] I. Lourenço, K. Rathke, V. Santana, M. Branco. The effects of corruption on earnings management. Corporate Governance: The International Journal of Business in Society, Vol 18, pp. $35-51,2018$

[32] R. Malagueño, C. Albrecht, C. Ainge, N. Stephens, N. Accounting and corruption: A cross country analysis. Journal of Money Laundering Control, Vol. 13, pp. 372 -393, 2010

[33]F. Mazzi, R. Slack, I. Tsalavoutis. The effect of corruption and culture on mandatory disclosure compliance levels: goodwill reporting in Europe. Journal of International Accounting, Auditing and Taxation, Vol. 31, pp. 52 - 73, 2018

[34] R.D. Picur. Quality of accounting, earnings opacity and corruption. Review of Accounting and Finance, Vol 3, pp. $103-114,2004$

[35] L. Pieroni, G. D'Agostino. Corruption and the effects of economic freedom. European Journal of Political Economy, Vol. 29 (March), pp. 54-72, 2013

[36] K. Ramanna, E. Sletten. Network effects in countries' adoption of IFRS. The Accounting Review, Vol. 89, pp. 1517-1543, 2014

[37] A. Riahi-Belkaoui, F.K. AlNajjar. Earnings opacity internationally and elements of social, economic and accounting order. Review of Accounting and Finance, Vol. 5 , pp. $189-203,2006$

[38] M.T. Rock, H. Bonnett, H. The comparative politics of corruption: Accounting for the East Asian paradox in empirical studies of corruption, growth and investment. World Development, Vol. 32, pp. 999-1017, 2004

[39] P.A. Voyer, P.W. Beamish. The effect of corruption on Japanese foreign direct investment. Journal of Business Ethics, Vol. 50, pp. $211-224,2004$

[40]L. Whitehead. High-level political corruption in Latin America: A transitional phenomenon. In J. S. Tulchin, \& R. H. Espach (Eds.), Combating corruption in Latin America, pp. 107-129,. Washington, DC: Woodrow Wilson Center Press, 2000

[41] S. Zaidi, E. Huerta, E. IFRS adoption and enforcement as antecedents of economic growth, International Journal of Accounting and Financial Reporting, Vol. 4, pp. 1-27, 2014

[42] M.R. Elhaj. Overview on the convergence of US GAAP into IFRS in Saudi Arabia, Universal Journal of Accounting and Finance, Vol. 7, pp. $96-105,2019$. DOI: 10.13189/ujaf.2019.070402.

[43] I. Septriana, Fuad. Factors affecting the understanding of IFRS in accounting students, International Journal of Higher Education, Vol. 9, pp. $302-309,2020$

[44] D.H.T. Phan, B. Mascitelli. Optimal approach and timeline for IFRS adoption in Vietnam: Perceptions from accounting professionals, Research in Accounting Regulation, Vol. 26, pp. $222-229,2014$.

[45] P. Andersson, N. Hellman. Analysts' evaluation of acquisition: Swedish survey evidence on IFRS knowledge and the use of accounting information for valuation purposes, Journal of International Accounting, Auditing and Taxation, Vol. 41, pp. 1 - 17 